\title{
Two Problems for Accepting as Intending*
}

Forthcoming, Ethics.

Please cite published version.

\author{
Nathaniel Sharadin \\ Syracuse University \\ natesharadin@gmail.com
}

August 22, 2017

\begin{abstract}
It's possible to accept or to reject a promise. According to a new proposal by Abraham Roth, accepting a promise involves intending that the promisee perform the promised action. According to Roth, this view is supported by rational symmetries between promissory acceptance and intention. Here, I show how these symmetries actually generate two problems for the view.
\end{abstract}

\section{Introduction: Accepting as Intending and Rational Symmetry}

Cyril promises to make Salah breakfast. Since promises aren't impositions, Salah can accept or reject Cyril's promise. ${ }^{1}$ Salah, prospectively peckish, accepts. What's involved in Salah's acceptance? According to a new proposal by Abraham Roth, by accepting Cyril's promise Salah intends that Cyril make him breakfast. ${ }^{2}$ Roth calls this view, naturally enough, Accepting as Intending, and offers several arguments in its favor. Here, I'm interested only in one, and only as background. As we'll see,

\footnotetext{
* Thanks to Patrick Connolly, Finnur Dellsén, Luke Elson, John Lawless, and Daniel Layman for feedback on an earlier version of this paper. Thanks also to two anonymous referees for their thoughtful comments.

${ }^{1}$ See Thomson (1990) and Roth (2016, esp. §I).

${ }^{2}$ Roth (2016, esp. §II, p. 92 and following). Technically, intending the promisor's action is one part of what the promisee does. The second part involves communicating the intention. Here, my focus is on the intentional aspect of acceptance; the communicative aspect doesn't affect my argument. So, in what follows, I'll say that accepting a promise just is intending the promisor's action.
} 
Roth's argument intuitively supports Accepting as Intending; but it simultaneously provides the materials for generating two related problems for the view.

A quick proviso. In this paper, I'm in the business of causing trouble for Accepting as Intending. You might already have doubts. For instance, you might worry about the notion of one agent intending another agent's action. For the sake of argument, in this paper I'll assume the proponent of Accepting as Intending can reassure us on all such matters. Even with the fully articulated view in front of us, I'll argue it faces two problems.

To begin: the relevant argumentative backdrop has two stages. First, we notice that promissory acceptance is subject to rational requirements strikingly similar to those governing intention. Next, we infer to the best explanation of this similarity that accepting a promise just is intending. Let's look at this idea in more detail, starting with the similarities exhibited by promissory acceptance and intention. Two similarities are particularly illustrative, one of which starts from the side of promissory acceptance, and the other from the side of intention.

First, from the side of promissory acceptance: it's irrational, we observe, to simultaneously accept mutually inconsistent promises, where this is a matter of the impossibility of both promised actions being performed. ${ }^{3}$ It's irrational, for instance, for Salah to simultaneously accept Cyril's promise to make him breakfast and Jack's promise to make him breakfast, on the assumption that it's not possible for Salah to be made two breakfasts. (Salah isn't a hobbit.) Now, we notice that intention is itself subject to a consistency requirement: it's irrational to simultaneously intend mutually inconsistent actions, where this is a matter of the impossibility of both actions being performed. ${ }^{4}$ So, that's the first striking similarity: both promissory acceptance and intention are subject to consistency requirements.

Second, from the side of intention: it's irrational to intend an action and fail to intend the (known) necessary means for that action. For instance, it's irrational for Cyril to intend to cook Salah breakfast but fail to intend to slice bread, assuming slicing bread is necessary to cook Salah breakfast. Now, we notice that promissory acceptance is itself subject to a means-ends coherence requirement: it's irrational for Salah to accept Cyril's promise to cook him breakfast knowing that in order for Cyril to do so Salah must tell Cyril where the eggs are, and for Salah not to intend to point Cyril to the eggs. ${ }^{5}$ So, that's the second striking similarity: both intention

\footnotetext{
${ }^{3}$ Roth (2016, p. 96).

${ }^{4}$ Roth (2016, p. 96). See also Bratman (1987); Harman (1986), both cited in Roth (2016).

${ }^{5}$ Roth (2016, p. 97).
} 
and promissory acceptance are subject to means-ends coherence requirements.

In the second stage of the argument, we ask: What explains these striking similarities in the rational requirements governing promissory acceptance and intention? The answer, supposing Accepting as Intending, is elegant and straightforward: since promissory acceptance is simply a special instance of intention, it's no surprise the former is governed by rational requirements similar to those governing the latter. Hence we receive inductive support for Accepting as Intending.

This argument, so put, looks pretty good. But this way of putting the argument, in terms of rational requirements "similar" or "like" each other, and an elegant explanation thereof, radically understates Accepting as Intending's commitments on this front. ${ }^{6}$ This is because the thesis that's meant to enjoy support from the argument is that accepting a promise to $\phi$ is identical to the promisee's intending that the promisor $\phi$. Hence if Accepting as Intending is true, it's not just that rational requirements on promissory acceptance and intention are strikingly similar, it's that they're (strikingly) identical. So we might begin by noticing striking similarities between rational requirements governing promissory acceptance and intention, but Accepting as Intending in fact entails something much stronger, viz. the same rational requirements govern the two.

This is a strong claim. It means that, for any true claim about the rationality of intending that $\mathrm{A} \phi$, there will be a paraphrastic true claim about the rationality of accepting A's promise that A $\phi$. The trouble, as I'll argue, is Accepting as Intending's commitment to this strong claim. Hence I'm happy to accept, for the sake of argument, that promissory acceptance and intention are subject to strikingly similar rational requirements. What I'll argue is that promissory acceptance and intention are not subject to exactly the same rational requirements, in the way Accepting as Intending is committed to thinking they are.

My argument, like the argument just canvassed, proceeds in two stages. In the first (§2), I'll present two problems for the view. In the second (§3), I'll diagnose the problems. The idea, then, is that the problems make us suspicious of Accepting as Intending, and the diagnosis confirms our suspicions. I'll conclude by considering six replies to my arguments $(\S 4)$.

\footnotetext{
${ }^{6}$ For Roth's statement using this language, see Roth (2016, pp. 96-7).
} 


\section{Two Problems for Accepting as Intending}

The problems I'm interested in involve cases where the rational requirements governing accepting a promise to $\phi$ and intending that the promisor $\phi$ come apart. In particular, I'll argue that Accepting as Intending delivers counterintuitive verdicts regarding the reasons promisors and promisees have. To that end, consider two principles. First:

Intend-Promote: If $\mathrm{S}$ intends that A $\phi$, and S's $\psi$-ing promotes A's $\phi$-ing, then there is a reason for $\mathrm{S}$ to (intend to) $\psi$.

Intend-Promote is an uncontroversial principle that says there's reason to (intend to) do what promotes what one intends. ${ }^{7}$ Now consider:

Accept-Promote: If S accepts A's promise to $\phi$, and S's $\psi$-ing promotes A's $\phi$-ing, then there is a reason for $\mathrm{S}$ to (intend to) $\psi$.

Accept-Promote follows from the conjunction of Accepting as Intending and IntendPromote: if accepting a promise to $\phi$ just is intending the promisor $\phi$, and there's reason to do what promotes what one intends, then there's reason to do what promotes what one accepts a promisor's promise to do. Accept-Promote is a paraphrastic instance of Intend-Promote: it's what we get by replacing 'intends that A $\phi$ ' with 'accepts A's promise to $\phi$.' According to Accepting as Intending, this should be licit, since accepting A's promise to $\phi$ just is intending that A $\phi$. But it isn't licit. The trouble, as I'll now explain, is that Accept-Promote delivers counterintuitive results. There are two closely related kinds of problematic results, and hence two corresponding problems. The first is easiest to see from the side of the promisee, the second from the side of the promisor. I'll take each in turn.

Consider, first, Salah's situation having accepted Cyril's promise to make him breakfast. Suppose Salah's slicing bread promotes Cyril's making breakfast. It turns out, then, that (given Accept-Promote) Salah has reason to slice bread. ${ }^{8}$

\footnotetext{
${ }^{7}$ But see $\$ 4.1$ for some qualifications. It's worth noting there is controversy over the idea of promoting an intention (or desire). See, for instance, Behrends and DiPaolo (2011); Lin (2016); Sharadin $(2015 \mathrm{a}, \mathrm{b})$. We can safely ignore this controversy at present. We might think of IntendPromote as a specific version of what Roth (2016, p. 97). calls the "means-ends coherence" requirement on intention.

${ }^{8}$ I'm supposing slicing the bread isn't itself a part of making breakfast, but that it does promote, i.e., make it more likely (see fn. 7), that Cyril will (successfully) make him breakfast. If intuitions differ, the case can be modified: perhaps what Salah does is ensure there's sufficient gas in the propane tank - this is clearly not in any ordinary sense part of making breakfast but it promotes Cyril's doing so. Alternately, the case presented in $\S 3$, where it's not at all plausible that the promisee's actions are part of the promisor's $\phi$-ing.
} 
Examples multiply: Salah has reason to do many things he didn't previously have reason to do. But these results are counterintuitive: Why is Salah, having accepted Cyril's promise, now in possession of reasons to help Cyril make breakfast? It's not just that Salah's reason to slice bread is outweighed by his reasons to do other things. It's that, intuitively, he has no reason at all to slice bread. More precisely: He has no reason to do so because he has accepted Cyril's promise to make him breakfast. Most precisely: He has no reason to do so in virtue of accepting Cyril's promise. Promissory acceptance doesn't itself generate reasons for Salah to do what promotes Cyril's keeping his promise. Imagine Salah was deliberating about what to do while awaiting his meal, and we told Salah that, if he had no more pressing matters to attend to, he should slice bread. He'd surely complain: "Cyril promised to make breakfast for me! I don't have any reason to help!" And that complaint seems exactly right.

Now, it's true Accept-Promote doesn't tell us how strong the reason is that Salah has, in virtue of accepting Cyril's promise, to help. And it's implausible to suppose the reason is maximally weighty, i.e., outweighs all other reasons Salah has. But it's equally implausible to suppose the reason is minimally weighty, i.e., is itself outweighed by all other reasons Salah has. So, there will be cases where his reason to help is at least strong enough to be taken into account in deliberation, and might even be decisive with respect to what he should do. And that's all we need for the counterintuitive result: Salah doesn't have any reason to help Cyril make him breakfast in virtue of accepting Cyril's promise to do so. ${ }^{9}$

I'll call cases such as this promisee-enlisting problems. Promisee-enlisting problems arise because, if accepting a promisor's promise to $\phi$ just is intending that the promisor $\phi$, the promisee can be rationally enlisted in helping the promisor $\phi$ via the quite general fact (Intend-Promote) that there's reason to do what promotes what one intends.

A clarification about the intended scope of this problem: the counterintuitive result is not that it's never the case that, having accepted a promise to $\phi$, a promisee now has reason to do something she didn't previously have reason to do. For example, if it's necessary for Salah to tell Cyril where the eggs are in order for Cyril to make Salah breakfast, then it's reasonable to suppose Salah has a reason he didn't have before, in virtue of accepting Cyril's promise, to point Cyril to the eggs. Instead, the counterintuitive result is that it's not always the case that, having accepted a promise to $\phi$, a promisee now has reasons to do anything at all that

\footnotetext{
${ }^{9}$ Thanks to an anonymous referee for urging clarity on this point.
} 
would promote the promisor's $\phi$-ing. ${ }^{10}$ Before diagnosing the promisee-enlisting problem, let's consider the second problem for Accepting as Intending, this time from the side of the promisor.

Suppose some further details about the Salah and Cyril's case. Suppose there are other guests in the house - Jack and Jess - and that Cyril is lazy. Suppose Cyril has just promised to make Salah breakfast (Salah accepted) and realizes it'd be great to have a sous-chef. What should Cyril do? What he should do, if he's rational, is promise everyone he can that he'll make Salah breakfast, hoping they'll accept. For, if they do, they'll then have reason to do what promotes Cyril's keeping his promise. (This is so for the same reasons Salah acquired such reasons, in the promisee-enlisting problem above.) And others having reason to help will presumably promote Cyril's own end of making Salah breakfast. So, given Intend-Promote, there's a reason for Cyril to promise Jack and Jess that he'll make Salah breakfast. Assuming it's relatively costless to do so, Cyril should actually promise Jack and Jess that he'll make Salah breakfast. If any (hopefully: both!) accept, there'll thereby be reasons (via Accept-Promote) for Jack and Jess each to do what'll promote Cyril's making Salah breakfast, e.g., heating the oven, slicing the bread, etc. Sous-chefs acquired!

But, again, this is very counterintuitive: Why should it be rational for Cyril, having promised Salah to make him breakfast, to now promise Jack and Jess that he'll make Salah breakfast? The subject of his promise is properly Salah, not Jack and Jess. It's not that Cyril's reasons to promise Jack and Jess are somehow outweighed by other reasons. It's that, intuitively, he has no reason at all, having promised Salah, to go on to promise Jack and Jess. At least, he has no reason to do so in virtue of having initially promised Salah. Imagine Salah hearing of such further promises. He'd surely complain: "You already promised me! Why are you going about making further promises regarding my meal?" That complaint seems, again, exactly right. I'll call cases such as this over-promising problems for Accepting as Intending. Over-promising problems arise because, if accepting someone's promise to $\phi$ is intending that the promisor $\phi$, there will be reason (via Intend-Promote) for the promisor to make her promise to as many agents as she reasonably can, hoping that (i) they'll accept and (ii) thereby be rationally enlisted (via Accept-Promote) into helping her $\phi$.

Below, I'll consider six replies to the promisee-enlisting and over-promising problems. But first I'll try to diagnose what's causing the problems. Doing so will pro-

\footnotetext{
${ }^{10} \mathrm{I}$ discuss this in further detail below ( $\S \S 3$ and 4.2 ).
} 
vide some theoretical weight to the intuitive doubt cast on Accepting as Intending by the cases.

\section{Diagnosing the Problems}

Let's begin with the promisee-enlisting problem. It's often observed that intending to $\phi$ closes deliberation about whether to $\phi$ and that this is part of the functional role, or point, of intention in our cognitive economy. ${ }^{11}$ Intention enables us to cease deliberation about whether to $\phi$ and begin deliberation about how to $\phi$. To this we can add, and it sometimes is added: it's a good thing we can intend in this manner, else we dither endlessly over what ends to pursue. Something similar is true of promising, and in particular of accepting a promise. Let me explain.

Suppose I book a flight. In order to make my flight, I must get to the airport by noon, and so I intend to do so. I must now figure out how to get to the airport by noon. Options present themselves: I could walk (exhausting), bike (cumbersome), hitchhike (dangerous), take a taxi (expensive), take a shuttle (crowded), use Uber (unethical?). I'm thinking aloud. You overhear, and offer to get me to the airport by noon. I tell you it's very important I not miss the flight. You seek to reassure me: "I promise to get you there by noon." Reassured, I accept your promise. Of course, I'm not done planning for the trip: there's more deliberation to come. But something important is now true of my subsequent deliberations.

One thing that's true, we should all agree, is that I can now close off my deliberations regarding getting to the airport. It's settled: you're giving me a ride. I can turn my attention to packing, booking hotels, etc. Assuming I don't have reason to doubt the sincerity of your promise, or your ability to fulfill it, the question of how to get to the airport is no longer open for me. That area of action is, as it were, outsourced: by accepting your promise, I've ceded responsibility for my getting to the airport to you.

This phenomenon, whereby accepting a promisor's promise that she'll $\phi$ is a way of the promisee's outsourcing responsibility for $\phi$-ing onto the promisor, and thereby closing off questions about how to $\phi$ in the promisee's deliberation, isn't uncommon or unfamiliar. It's a paradigmatic description of what happens, at the level of the promisee's deliberations, when a promisee accepts a promise. We can put this, in harmony with the oft-observed claim about intention noted above, in terms of the functional role, or point, accepting a promise plays in our cognitive economy: like

\footnotetext{
${ }^{11}$ C.f. Bratman (1984, 1987); Holton (2008).
} 
intending, it's a way of closing off deliberation about $\phi$-ing. Intention closes off deliberation about whether to $\phi$, and accepting someone's promise to $\phi$ closes off deliberations about how $\phi$-ing shall be achieved: the promisor is now responsible for $\phi$-ing.

But, and here's the point, if Accepting as Intending is correct, then what I do when I accept your promise is form some further intention, viz. that you get me to the airport by noon. But that's not a way of closing off deliberation about how I shall get to the airport! For now I might well concern myself with executing this further intention; I now have reason to fill your car with gas, to put directions in your mailbox, and, quite generally, to do what will promote your getting me to the airport. The point here is not that I can't intend for you to get me to the airport. Of course I can do that. The point is that when you promise to get me to the airport and I accept, what paradigmatically happens is that I can then ignore the details of how this will be accomplished, trusting you to do what it takes. But if what I do in accepting your promise is thereby intend that you'll do it, I'm still indeed, ipso facto - responsible for achieving the promised action. In other words, I've been enlisted in executing the promise, simply by accepting it. If Accepting as Intending is correct, accepting a promise isn't a way of outsourcing the promised action: it's instead a (somewhat complicated) way of enlisting the promisor into the project of achieving the promised action without - and this is crucial - de-enlisting the promisee.

Here is another way to put the point: once I intend to fly, I thereby acquire reason to do what promotes my flying. Why? Because of Intend-Promote. But by the same token, once I accept your promise to take me to the airport and - if Acceptance as Intending is correct - thereby intend you to take me to the airport, I thereby acquire reason to make sure your car is filled with gas, to send you reminders, etc. In short: to do what promotes your taking me to the airport. Why? Because of the very same principle, i.e., Intend-Promote. So, the problem I'm highlighting here is that, if accepting your promise to get me to the airport is just a matter of forming another intention, then I'll have reason to do all manner of things I intuitively have no reason to do regarding your fulfillment of your promise in virtue of forming this new intention for you to fulfill it. That's the counterintuitive result.

Below I'll consider replies to this idea, including the reply that promises to $\phi$ are (implicitly) promises to $\phi$-without-any-help-from-the-promisee. But first, let's turn to the over-promising problem. The theoretical trouble is more subtle, and hence more difficult to see, in the over-promising problem. It's easiest to see from 
the side of the promisee. So that's where I'll begin.

Promising generates moral obligation: having promised to $\phi$, the promisor is now morally obligated, to the promisee, to $\phi$. In other words, promising enjoins a new normative relationship between promisor and promisee with respect to the promisor's $\phi$-ing. One aspect of this relationship is that if the promisor fails to $\phi$ the promisee has a distinctive moral complaint available to her not available to other agents. The promisee can, in virtue of having been promised, appropriately direct a distinctive kind of moral blame, or resentment, to the promisor for her failure to $\phi$. Agents other than the promisee might, of course, be in a position to issue a generalized moral complaint toward the promisor for her failure to keep a promise, in the same way any agent is positioned to condemn other agents' failures to fulfill their moral obligations. The point here is that promisees stand in a special position to direct a distinctive complaint to their promisors, and this is because promisees are the ones who were promised. Now, standing in this relationship, being situated to make this special complaint, doesn't theoretically preclude other agents from standing in a symmetrical relationship. Others might also be in a position to complain in the same distinctive way about an agent's failure to $\phi$ since, after all, it's possible for a promisor to make the same promise to multiple promisees. However, ordinarily, when someone promises you she'll $\phi$, you naturally expect to be the only one so situated, unless you know, or suspect, that she has, or will, similarly promise others that she'll $\phi$.

But here's the odd thing: given Accepting as Intending, this natural expectation - that when someone promises you she'll $\phi$, she's thereby enjoined a significant normative relationship between just you and her - is radically mistaken. For it's always rational for the promisor to promise any promisees she reasonably expects to accept. By doing so, she hopes to enlist them, via Accept-Promote, in executing her promise. By doing so, she also enjoins the same normative relationship between subsequent promisees and herself as that enjoined by promising you. Moreover, given Accepting as Intending, this isn't only possible, you should expect it to occur. Whenever someone promises you she'll $\phi$, you should expect, ceteris paribus, she'll also promise others she'll $\phi$. And this seems wrong. Being promised, and accepting someone's promise, seems personal, intimate, in a way that's disrupted when it's accompanied by the thought that the promisor will soon be off to make the same promise to others when she's done with you. To reiterate: the problem is not that it's possible, or even likely in some cases, that a promise has more than one promisee. The problem is that while it's natural to think of this as the exception 
to the rule, Accepting as Intending says it is the rule.

So: Accepting as Intending doesn't do justice to the significance of the normative relationship a promisee naturally expects is enjoined between the promisor and herself, since it not only allows for that same relationship to be enjoined between the promisor and other promisees - something all should allow - it also makes the proliferation of the relationship ubiquitous - and that's quite odd indeed. It's odd because, in promising, absent reasons to think otherwise, we naturally expect to uniquely stand in this special relationship with a promisor. But if Accepting as Intending is correct, this natural expectation is radically mistaken. I'll turn now to six replies to these two problems.

\section{Replies 83 Rejoinders}

\subsection{Accepting as Intending isn't committed to Accept-Promote}

Reply: Both the promisee-enlisting and the over-promising problem rely on AcceptPromote, i.e., the principle that says if you accept someone's promise to $\phi$, and $\psi$-ing promotes her $\phi$-ing, then there's reason for you to $\psi$. But: Accepting as Intending isn't committed to Accept-Promote. So, Accepting as Intending faces neither problem.

Rejoinder: Accepting as Intending is committed to Accept-Promote. Recall how we arrived at Accept-Promote, viz. via Intend-Promote. Intend-Promote is an uncontroversial principle about the reasons agents have to do what promotes what they intend. I say uncontroversial, but we might quibble over the details. I'm happy to admit that Intend-Promote might require modification. But such modification does not materially change the facts on the ground. For corresponding to each modification of Intend-Promote there's a version of Accept-Promote entailed by the combination of Intend-Promote and Accepting as Intending. These versions of Accept-Promote are trivial to generate: simply replace 'intends that A $\phi$ ' with 'accepts A's promise to $\phi$.' So, while insisting on modifying Intend-Promote (and so Accept-Promote) might belay the problematic results, it doesn't block them.

\subsection{Rejecting Accepting as Intending Leaves Unexplained Reasons}

Reply: Suppose Rose promises to return a book on my behalf and I accept. Intuitively, I have reason to leave the book where she can find it. So, promisees some- 
times have reason to do what promotes a promisor's $\phi$-ing. Accepting as Intending easily explains this: it's because promisees always have reason to do anything that promotes a promisor's $\phi$-ing. Rejecting Accepting as Intending leaves us with unexplained reasons. ${ }^{12}$

Rejoinder: If we reject Accepting as Intending, as I'm urging, we can nonetheless explain such reasons by appeal to a familiar feature of promises. Here is how that explanation goes: sometimes (perhaps often) some (but not all) promise-promoting actions on the part of a promisee are implicitly included as conditions of the promise. In our example, Rose's promise to return the book on my behalf is (implicitly) a promise to return the book conditional on my providing her with the book (or at least not hiding it from her). On this way of understanding things, accepting Rose's promise means I'll either provide her with the book (and then she's obliged to return it) or that I won't (and she's free of any obligation to do so). Assuming I want Rose obligated to return the book on my behalf, I then have reason to provide her the book. ${ }^{13}$ But, intuitively, her promise isn't (implicitly) a promise to return the book conditional on, e.g., my driving her to the library, sending her reminder emails, etc. That is why I don't have any reason to do such things, having accepted Rose's promise, despite the facts that (i) those things promote Rose's returning the book and (ii) I might have reason to do some things that promote her returning the book. ${ }^{14}$ This isn't an ad hoc amendment to the view that only earns its keep in explaining the unexplained reasons: it's a familiar idea that promises often contain such implicit "escape clauses" or conditions, some of which involve actions on the part of the promisee.

\subsection{There Is a Restriction on Appropriate Promisees}

Reply: The over-promising problem arises when a promisor extends her promise beyond the initial promisee. But: there's a restriction on who can be the appropriate promisee of any given promise that precludes extending promises in this way. So, Accepting as Intending doesn't face the over-promising problem.

\footnotetext{
${ }^{12}$ Thanks to two anonymous referees for presenting versions of this reply.

${ }^{13}$ See fn. 23 for more on this point.

${ }^{14}$ What determines the conditions that are in this way implicitly involved in promises? Roughly, convention: it's precisely those actions it doesn't seem odd, or counterintuitive, to think are required of a promisee that can be understood in this way, as conditions of the original promise. As promises differ in content, context, promisor / promisee pairs, etc. so they will vary in their implicit conditions.
} 
Rejoinder: This is an attempt to block the over-promising problem by blocking the possibility, or appropriateness, of promising further agents to $\phi$, given that one has already promised one particular agent to $\phi$. I offer three related points in response.

First: It's clearly possible to promise more than one agent to $\phi$. The thought behind the reply is that this is somehow inappropriate. But, at least sometimes, this is completely appropriate. For instance, a student can promise all the members of her dissertation committee that her thesis will be completed by term end. Moreover, she can do so by first promising one of them, then promising the next, etc. So it cannot be that there's a blanket restriction, grounded in the nature of promising, on extending promises beyond an initial promisee.

Second, and relatedly: Since it's possible and sometimes appropriate to extend promises to multiple promisees, the thought must be that in cases of over-promising there's a theoretically principled way of restricting the appropriate promisees for any given promise. But I'm at a loss to see what such a restriction could be. It cannot be a restriction grounded in the nature of promising. It equally cannot be a restriction grounded in the content of particular promises, since it's possible to imagine contexts in which promises with those contents are appropriately extended to further promisees. So, I'm not optimistic about the prospects for the proponent of Accepting as Intending providing a non-ad hoc restriction that delivers the required results. At the very least, we're owed a story here about the relevant restriction. ${ }^{15}$

Third: Notice that this reply attempts to weaken the strongly counterintuitive results that over-promising is always (or ever) rational. But someone who rejects Accepting as Intending will also find these results equally counterintuitive. The important thing is that, if one rejects Accepting as Intending, one doesn't face this problem. So, it does no good to point to the counterintuitive results and insist that there must be some theoretically perspicuous way of restricting appropriate promisees. For the opponent of Accepting as Intending will agree that there must be some way to block the results; only, she doesn't need to resort to specifying a theoretical restriction on appropriate promisees to do so. She need only point to her rejection of Accepting as Intending.

\footnotetext{
${ }^{15}$ But see $\S 4.4-5$ below for further discussion.
} 


\subsection{Over-Promising Won't Normally be Effective at Promoting $\phi$-ing: Reasons- Responsiveness}

Reply: The over-promising problem only arises if it's normally reasonable for a promisor to think that additional promisees are rational in the sense that they are aware of and responsive to their reasons for performing actions that are grounded in their promissory acceptances. But this thought isn't normally reasonable: it's normally unreasonable to suppose that, even if further promisees were to accept one's promise to $\phi$, they would be responsive to the reasons they thereby acquire to promote one's $\phi$-ing. We know this isn't normally reasonable via our actual experience. After all, it's not true that promisors typically go about over-promising! The thought continues: they don't do so because it's an ineffective strategy for promoting their promises. Hence, Accepting as Intending doesn't face the over-promising problem.

Rejoinder: This reply is in an odd dialectical position: the proponent and opponent of Accepting as Intending agree that over-promising won't be effective at promoting promised actions. According to Accepting as Intending, this is because further promisees are for some reason systematically insensitive to the reasons they acquire via promissory acceptance to promote the promised action. According to the opponent of Accepting as Intending, this is because accepting a promise isn't a matter of intending and so doesn't generate the relevant reasons. I don't see any reason to prefer the former explanation to the latter. Indeed, there seems to be a clear cost to taking the former route: it requires thinking that, at least in this domain, agents are (for an as yet unexplained reason) systematically insensitive to their reasons. So, if the thought is that the absence of real-life, honest-to-goodness over-promising is explicable by Accepting as Intending, I'm happy to grant it might be. But it's equally explicable by the opponent of that view, since the opponent isn't committed to thinking it's even possible to germinate the space of reasons via over-promising. Moreover, the opponent of Accepting as Intending appears to have the upper-hand in explaining the lack of actual over-promising in the wild, for she doesn't need to encourage pessimism about agents' rational capacities to do so.

\subsection{Over-Promising Won't Normally be Effective at Promoting $\phi$-ing: Non-Acceptance}

Reply: Potential promisees will refuse to be "drawn in" to promises: they will not accept the promisor's promissory overtures. For instance, if you promise me 
your next meal will be a burrito, I might reasonably tell you to leave me out of it. Moreover, promisors are in a position to know this. So, it won't be reasonable for promisors to over-promise. ${ }^{16}$

Rejoinder: My rejoinder has two parts. First: it remains possible that, sometimes, it will be reasonable to attempt over-promising, even if it's true that, normally, it won't be successful. This will be so in conditions where the attempt is relatively costless. In my view, this remains an unacceptable result. More importantly, second: if we reject Accepting as Intending we can agree that (i) over-promising won't normally be effective at promoting $\phi$-ing and (ii) potential promisees will refuse to be "drawn in." And we can explain both facts: (i) is explained by the rejection of Accepting as Intending (see §4.4). And (ii) is in turn explained by explaining potential promisees' reluctance to accept (over-) promises in terms of their reluctance to stand in the special relationship engendered by promises to the promisor.

To elaborate on (ii): rejecting Accepting as Intending doesn't require rejecting the claim that accepting a promise involves any sort of important normative commitment. Indeed, as we saw above ( $§ 3$ ), it's a familiar idea that there's a special normative relationship engendered between a promisor and a promisee: the promisee is in a position to direct a particular kind of moral resentment toward the promisor should she fail in her promise. So, a possible explanation of a potential promisee's unwillingness to be "drawn in" to a promise is that she's unwilling to stand in this relationship to the promisor, at least with respect to the content of this promise. (For instance, I might not want to put myself in a position where I should blame you for failing to eat a burrito. And so I might ask you to "leave me out of it" when it comes to such things.)

\subsection{A promise to $\phi$ is a promise to $\phi$-without-help-from-the-promisee}

Reply: When a promisor promises to $\phi$ she implicitly promises to $\phi$-without-anyhelp-from-the-promisee. Hence a promisee's acceptance doesn't enlist the promisee in $\phi$-ing. For, anything the promisee might do to promote the promisor's $\phi$-ing would obviously not promote the promisor's $\phi$-ing-without-any-help-from-the-promisee.

Rejoinder: Something like this idea appears to be Roth's, when, in the course of worrying about something a version of the promisee-enlisting problem, he says that

\footnotetext{
${ }^{16}$ Thanks to an anonymous referee for suggesting this reply.
} 
Accepting as Intending can capture an important asymmetry between the promisor and the promisee:

Surely there is such an asymmetry [between the promisor and promisee], but it's not hard to account for it. [...] [I]t might be implicit in the promise (and therefore in the acceptance) that the promisor will address everything that comes up that would need to be taken care of in order for the promisor to $\phi$. ("Don't worry about it; I'll take care of everything. I promise.") Thus, even though the promisee intends the promisor's $\phi$-ing, the promisee doesn't normally have to do anything. ${ }^{17}$

This idea has two problems.

First: in order for this reply to work, it must be true that normally a promisor implicitly promises to $\phi$-without-any-help-from-the-promisee. But it's simply false that, normally, when a promisor explicitly promises to $\phi$ what the promisor implicitly promises is to $\phi$-without-any-help-from-the-promisee. Roth himself appears, accidentally perhaps, to acknowledge this point. For, as Roth points out, we do sometimes promise to $\phi$-without-any-help-from-the-promisee when promising to $\phi$. We do this when we say, as Roth says: "Don't worry about it; I'll take care of everything. I promise." 18 But, natural as it is, this bit of language isn't evidence that when we promise to $\phi$ what we ordinarily implicitly promise is to $\phi$-withoutany-help-from-the-promisee. Instead, this is a way of remarking on the fact that we have a way, in the language, of promisors assuring promisees that what the promisor means to be promising is $\phi$-ing-without-any-help-from-the-promisee. But if the default, normally implicit promise when a promisor promises to $\phi$ is a promise to $\phi$-without-any-help-from-the-promisee, we'd expect exactly the opposite thing to be true. We would expect to find a way of marking out this promise as one (merely) to $\phi$, and not to $\phi$-without-any-help-from-the-promisee. What we find instead is a way of marking out this promise as one to $\phi$-without-any-help-from-the-promisee and not (merely) to $\phi$. We find assurances where we wouldn't expect to need them, and don't find hedges where we'd expect them to be. So, I don't think we have any reason to grant that when someone promises to $\phi$ what they ordinarily implicitly promise is to $\phi$-without-any-help-from-the-promisee. ${ }^{19}$

\footnotetext{
${ }^{17}$ Roth (2016, p. 97, emphasis added).

18 ibid.

${ }^{19}$ The fact that promises to $\phi$ are not normally implicit promises to $\phi$-without-any-help-from-thepromisee doesn't preclude there being independent reasons for promisees not to help promisors $\phi$. For instance, it might be that helping the promisor $\phi$ communicates a lack of trust in the promisor's ability to $\phi$; or, relatedly, it might involve a failure to respect the promisor's autonomy.
} 
Second: Even supposing promisors normally implicitly promise to $\phi$-withoutany-help-from-the-promisee, this won't make all the problems go away. Recall Cyril and Salah. Suppose, for the sake of argument, that in making his promise to Salah Cyril implicitly promises to make Salah breakfast without any help from Salah. This fact doesn't affect whether and to what extent it's rational for Cyril to go on to make promises to Jack and Jess to cook Salah breakfast. Of course, Cyril should not (implicitly) promise Jack and Jess that he'll make Salah breakfast without any help from the promisees. For, the point of promising Jack and Jess, is to rationally recruit them, via Accept-Promote, into making Salah breakfast. But the troubling thing about the over-promising problem, as we saw, was not that Cyril will receive help in fulfilling his promise to Salah. It was that the significance of the normative relationship engendered by Cyril's promise to Salah is distorted by the fact that it's always rational for Cyril to make these further promises and that Salah is in a position to know this.

\section{Summary}

Accepting as Intending looks like a promising view about promissory acceptance. It seems well-positioned to explain striking similarities between rational requirements governing intention and promissory acceptance. But because the view identifies promissory acceptance with intention, it entails that paraphrastic versions of rational principles governing intention also govern promissory acceptance. ${ }^{20}$ In particular, it entails that since Intend-Promote governs intention, Accept-Promote governs promissory acceptance. But Accept-Promote does not govern promissory acceptance. If it did, then promisees could be rationally enlisted into achieving promised actions. This isn't correct: if it were, then promissory acceptance wouldn't be capable of serving the function it normally does in our deliberative economy. Perhaps

But the existence of reasons not to help the promisor $\phi$ won't help the proponent of Accepting as Intending, for the trouble with that view isn't that it entails that reasons to help are never outweighed. We can grant that they might be outweighed (e.g., by the reasons just mentioned). The trouble with the view is that (absent the relevant explicit condition in the promise) it entails the existence of the reasons to help in the first place. See $\S 3$ above. Thanks to an anonymous referee for suggesting this point.

${ }^{20}$ Perhaps one could modify Roth's account to say that promissory acceptance isn't intending that the promisor $\phi$, but instead that the promisor be under an obligation to $\phi$. This would arguably avoid the troubling implications articulated here. I do not know whether Roth would welcome such a modification, but I see two reasons for hesitation on his behalf. First, such a view wouldn't involve intending another agent's action, a feature of Roth's view he thinks is important, and novel. Second, it's not clear to me that such a view could do the work Roth puts to his original view, especially when it comes to explaining Scanlon's Expectation view (see §V of Roth (2016)). Thanks to an anonymous referee for suggesting this possibility. 
worse, if Accept-Promote governed promissory acceptance, it would be rational for a promisor to promise as many agents as could reasonably be expected to accept. But, again, this isn't correct: if it were, then the significance of the normative relationship engendered by promise-making and promissory acceptance would be

radically distorted. So: It might turn out that promissory acceptance is closely related to intention, but the former isn't simply identical to the latter.

References

Behrends, J. and DiPaolo, J. (2011). Finlay and Schroeder on promoting a desire. Journal of Ethics and Social Philosophy, pages 1-6.

Bratman, M. (1984). Two faces of intention. Philosophical Review, 93:375-405.

Bratman, M. (1987). Intentions, Plans, and Practical Reason. Harvard University Press, Cambridge, MA.

Harman, G. (1986). Change in View. MIT Press, Cambridge, MA.

Holton, R. (2008). Partial belief, partial intention. Mind, 117:27-58.

Lin, E. (2016). Simple probabilistic promotion. Philosophy and Phenomenological Research.

Roth, A. S. (2016). Intention, expectation, and promissory obligation. Ethics, $127: 88-115$.

Sharadin, N. (2015a). Problems for probabilism about promotion and an alternative. Philosophical Studies, 172(5):1371-1386.

Sharadin, N. (2015b). Reasons and promotion. Philosophical Issues: A Supplement to Nous.

Thomson, J. J. (1990). The Realm of Rights. Harvard University Press, Cambridge, MA. 